\title{
Analysis of Factors Influencing Public Capital Investment in Nigeria
}

\author{
Cordelia Onyinyechi Omodero, PhD, ACA.
}

\author{
Clifford University Owerrinta, \\ Abia State, Nigeria
}

Doi: 10.36941/jesr-2020-0007

\begin{abstract}
There are several factors that affect successful execution of public capital projects in every economy. This study specifically investigates the influences of selected macroeconomic factors such as: inflation, exchange rate, total expenditure, population, debt servicing and Real GDP on government capital investments using data that cover a period from 2000 to 2017 . Using ordinary least squares technique, the findings reveal that Real GDP and population have insignificant negative impact on capital investments, while debt servicing has a significant negative influence on government capital expenditure. Inflation rate does not exert any influence but exchange rate and total expenditure have significant positive impact on capital expenditure. The implication is that a lot of funds go into debt servicing, thereby denying the masses of adequate infrastructural provisions. Due to poor funding of local industries, they lack the capacity to affect the economy positively such that the size of the Real GDP is negatively influencing the public capital investment. Therefore, the study has made some recommendations which could help our policy makers in their decision to ensure that investment in capital projects and infrastructures in the country is given the basic consideration to achieve its economic objectives. Above all the domestic industries and agriculture should be well financed since inflows from them can help to carry out more capital projects and reduce the country's level of borrowing.
\end{abstract}

Keywords: Public capital investment, macroeconomic factors, population, inflation, RGDP

\section{Introduction}

Public capital investment is the government capital spending on capital projects, provision of infrastructures as well as major repairs, restructuring and overhauling of the existing ones to match with the present needs of the citizens. In all developing nations, public investment serves a very important purpose and is very paramount for a sustainable economic development. Governments spend on capital projects like roads construction, airports, building of new schools, health care centers, electricity generation, telecommunications, buying of new software, specialist hospitals etc., to be able to adequately develop an economy. These categories of expenditures are referred to as capital investments and are made on capital projects which help to maintain or improve government properties, usually called infrastructures (The City of Portland Oregon (TCPO), 2018).

Capital expenditures may be on short or long term capital projects. For instance in Portland, a capital project has to satisfy certain conditions such as: it must be a new construction, expansion, renovation, or replacement project for an existing facility or facilities before it could be classified as capital expenditure (TCPO, 2018). They have a productive life of several decades and help to provide a more efficient economy (Kalemi \& Prodani, 2015). In Nigeria, the government spends on road 
construction and maintenance, building of schools, hospitals and health centers. Recently due to flooding, oil spillage, desert encroachment, landslide, deforestation, crop pests, environmental pollutions, insurgencies and other natural disasters in some locations in the country, public investment has also included government interventions to mitigate the effects of these catastrophes on the citizens.

However, the mismatch between the Nigerian economic development and huge rise in government capital expenditure over the years gives cause for enquiry especially on the part of economic growth advancement and development. The challenge of raising additional funds and pursuit for more tax revenues to cope with increasing government spending calls for worry.

The problem of abandoned projects in Nigeria has become alarming and a long term impediment to economic growth in the country, despite the huge government budgets and spending on capital projects. The issue has been a natural phenomenon and a recurring decimal with almost every administration that comes and goes. When a particular administration goes, the successor seems to overlook the ongoing projects of the immediate past administrator (predecessor), which means an administration is succeeded but the projects and certain responsibilities are not succeeded. This trend gives everyone cause for enquiry and concern, hence this paper tries to investigate the role of economic factors in affecting government's capital expenditures in Nigeria, despite other underlying factors such as corruption, greed and selfish interest that are common in the country and among public officers.

Therefore, the effect of macroeconomic factors on government capital expenditure in Nigeria ought to be evaluated. This paper specifically, seeks to examine the extent to which macroeconomic factors such as inflation, exchange rate, total expenditure, debt servicing, population of the country, and the real GDP influence government investment in capital projects in Nigeria.

\section{$1.1 \quad$ Hypotheses}

The following null hypotheses have been formulated to guide the study.

Ho1: Total expenditure does not have significant impact on the public capital investment.

Ho2: Real GDP does not significantly affect the public capital investment.

Ho3: Population does not have significant influence on public capital investment.

Ho4: Inflation does not significantly affect public capital investment.

Ho5: Exchange rate does not have significant influence on public capital investment.

Ho6: Debt servicing does not have significant effect on public capital expenditure in Nigeria.

\section{Literature Review}

The literature review has been divided into three phases which are the conceptual framework, theoretical review and the empirical review.

\subsection{Conceptual Framework}

The conceptual framework portrays how the explanatory variables (Total expenditure, Real GDP, Population, Inflation, Exchange rate and debt servicing) affect the dependent variable (Capital investment). 


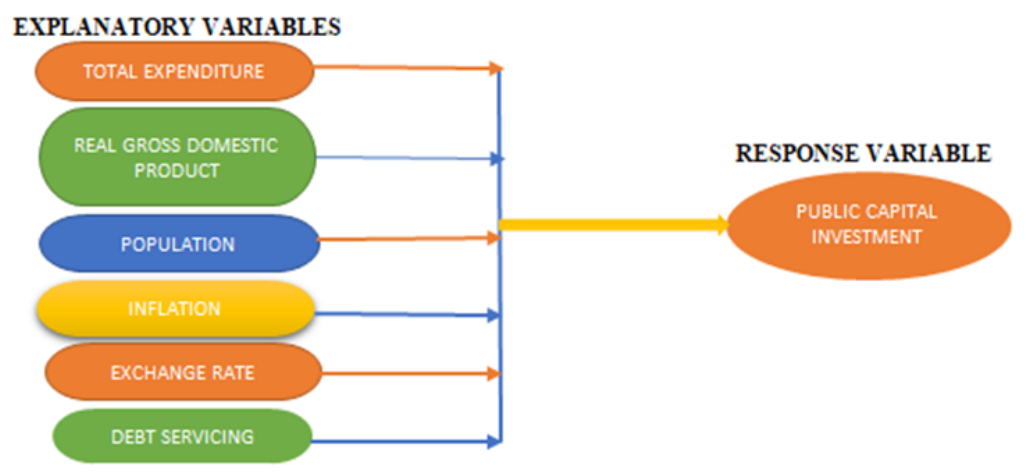

Figure 1: Conceptual model for factors that influence government capital investment.

Source: Author's Desk Research, 2019.

\subsubsection{Conceptual definitions}

In the context of this study, total expenditure comprises government capital and recurrent expenditure. Recurrent expenditure consists of routine expenses that are used for day to day administrative purposes. It includes: salaries and allowances paid to employees, operational costs in form of travelling and accommodation, telephone, electricity and water bills, bank charges and other services (Controller of Budget, 2015). Real GDP is a gross domestic product adjusted for inflation or deflation. It provides the worth of finished goods and services at constant base-year prices. It comprises variations in the over-all value of goods and services in a particular year using base-year prices, which help to depict precisely an economy's growth level (My Accounting Course, 2018).

The term capital expenditure is used to explain the outflow of funds used to acquire assets that are anticipated to give value to a business for more than a single accounting period or financial year, for instance: land, building, machinery, software, vehicles computers and office equipment (Accounting Tools, 2017).

Population is defined as all citizens residing in, or momentarily far away from a country, and foreigners permanently living in a country. This is a pointer showing the number of people that usually reside in an area which includes: national armed forces and diplomatic personnel located abroad, merchant seamen at sea, civilian aliens and displaced persons resident in the country. The following are however excluded: foreign armed forces and diplomatic personnel stationed in the nation, civilian foreigners temporarily in the country. Population estimates are a common demographic device. They provide a basis for other statistical predictions, which helps governments in their decision making. It is measured in terms of annual growth rate and in thousands of people (Organization for Economic Co-operation and Development (OECD), 2018).

Inflation denotes the general increase in the consumer price index (CPI), which is a weighted average of prices for different goods. Annual inflation is the percentage change of the CPI compared to the same month of the previous year (Focus Economics, 2018). Therefore, inflation rate is the rate at which prices increase over time, resulting in a fall in the purchasing power/value of money. Exchange rate is the amount at which a particular nation's currency can purchase another country's legal tender. Exchange rate can be either fixed or floating. Fixed exchange rate is determined by the Central Banks of a nation whereas floating exchange rate is decided by the forces of demand and supply (The Economic Times, 2018). Debt service is the amount of money necessary for settlement of loan (interest and principal) within a specific period of time (Investopedia, 2018). It is also referred to as the amount of money agreed by a person or an institution to pay for a number of periods during the lifetime of a loan (My Accounting Course, 2018). 


\subsection{Theoretical Review}

The theories underpinning this study have been stated below.

\subsubsection{Adolph Wagner's Law of Increasing State Activity}

Adolph Wagner (1883), the German economist did an all-inclusive research which relates to rise in government expenditure in the late $19^{\text {th }}$ century. The Law of Increasing State Activity was a product of the Wagner (1883) comprehensive research on government expenditure. The law Wagner advocated put forward that government tasks and responsibilities rise in the same proportion with a nation's economic development. According to him, various countries have been assessed at diverse periods and it has become conventional that the responsibilities of both the central and local governments increase, as new roles are assumed while efforts are made to carry out both old and new tasks efficiently and perfectly. In this way economic needs of the public to a large extent and in a more suitable manner, are met by the Central and Local Governments.

From Wagner's study on Germany economic growth, the result discloses that the activities of the central and local government in developed countries constantly increase. As the government takes up fresh responsibilities for the benefit of the citizens, the functions become wider and indepth. It leads to more efficiency in government roles and also increases public investment.

\subsubsection{The Peacock-Wiseman Hypothesis}

Peacock and Wiseman (1961) did a research which was based on Wagner's Law. They examined the public expenditure in U.K. from 1891 -1955. They discovered that Wagner's Law is still valid and relevant. Peacock and Wiseman (1979) went further to state that the growth in public spending hinges critically on revenue collection which enables the government to be able to provide public goods and services and make public capital investments. These public investment are done through revenues emanating from tax payments and so the government cannot disregard this important source of revenue since it is an avenue to satisfy the increasing demands from people for public goods and services. In times of wars, droughts and other forms of natural disasters, the demand for government interventions increases, therefore, the government needs more funds to meet the demands from the citizens.

\subsection{Empirical review}

\subsubsection{Foreign empirical studies}

Kimaro, Keong and Sea (2017) employed panel data of Sub Saharan Africa low income economies spanning from 2002 to 2015 to investigate the effect of government expenditure on economic growth. All data were collected from World Development Indicators (WDI) database. The response variable was the GDP per Capita which was used to measure economic growth of selected countries, while the control variables were: gross capital formation, population, inflation, and consumption expenditure. The study made use of Generalized Methods of Moments (GMM) and the result indicated that increasing government expenditure accelerates economic growth of low income countries in Sub Saharan Africa, but the study found no evidence that government efficiency propels government expenditure to influence economic growth. The study suggested that fiscal policy makers in the Sub Saharan Africa low income region should ensure that government spending is used to enhance economic growth.

Maingi (2017) investigated the impact of government expenditure on economic growth in Kenya using Vector Auto Regression estimation technique and annual time series data covering the period from 1963 to 2008 . The rapid growth in government expenditure in Kenya became a concern to policy 
makers, hence the study to verify the extent to which government expenditure affects economic growth. The data collection include: expenditure on government investment, physical infrastructure, education, health care, public debt servicing, economic affairs, general administration and services, defense, public order and national security and government consumption. The data sources were the Kenya government documents and International financial statistics publications. The results of the analysis indicated that, government expenditure on investment, physical infrastructure, education, health care, public debt servicing, economic affairs, general administration and services, defense, public order and national security and government consumption have effect on economic growth. The study therefore concluded that all government budgets and reforms on expenditure affect economic growth.

Nguyen (2017) researched on the relationship between public expenditures and GDP growth in 63 provinces/cities of Vietnam using regression analyses method with three predictor variables (total public expenditure, expenditure on development investment, social and economic services). The time series data spanned from 2013 to 2015. The regression result revealed that expenditure on development investment, social and economic services contribute significantly and positively to the economic development of localities. The total expenditure did not have any relationship with growth. One of the recommendations is that localities should endeavor to embark on investments that are focused on key essential areas necessary to push economic growth.

Kalemi (Jakupi) and Prodani (2015) investigated the impact of macroeconomic factors on public capital expenditures in Albania using Wagner Model and time series data spanning from 1996 to 2013. The study considered government activities and the challenge of consistent discrepancy between government expenditure and the level of economic development witnessed in Albania due to political developments and complex structure of government expenditure. The data collection were on government expenditures, real GDP, domestic debt, deposit rates, lending rates, inflation, and private investment. All data used for the study were sourced from Bank of Albania, Ministry of Finance, Albania Statistic Institution and European Commission Statistic Institution. Statistical Package for Social Sciences (SPSS) was used to carry out the multiple regression analysis and the result revealed the existence of no correlation between government expenditure and economic factors in Albania. The result also indicated that economic factors did not have any effect on government capital expenditures.

Kapunda and Topera (2013) investigated government expenditure composition and how it affects economic growth in Tanzania. The study made use of ordinary least square method and time series data which covered a period from 1965 to 2010. The data sources were National Bureau of Statistics (Tanzania), Bank of Tanzania (BOT), Ministry of Finance and Economic Affairs (Tanzania), Planning Commission (Tanzania), various Government Ministries, Departments and Authorities, World Bank and IMF Reports. The dependent variable was the Real GDP while the explanatory variables were: total government expenditure, sectorial government expenditure (both recurrent and capital), and terms of trade, foreign real interest, real exchange rate, and population growth rate. The findings revealed that capital expenditure and terms of trade significantly and positively contribute to economic growth. Others were positive but not significant except recurrent expenditure and few others that had insignificant negative impact on growth. The policy implication is the need to move a little more from recurrent to capital expenditure to promote economic growth in Tanzania.

\subsubsection{Empirical studies from Nigeria}

Omodero (2019) investigated the effect of government general spending on human capital development in Nigeria using ordinary least squares method and secondary data that covered a period from 2003 to 2017 . The study employed both the capital and recurrent expenditures and found evidence that the recurrent expenditure had a favorable effect on human development index (HDI), but the capital expenditure impacted negatively but insignificantly on HDI. However, this present study attempts to examine the factors affecting the performance of government public capital 
investment which includes both the HDI and general public infrastructures. Idris and Baker (2017) employed Autoregressive Distributed Lag (ARDL) model to investigate the relationship between government expenditure and economic growth in Nigeria. The study made use of time series data spanning from 1980 to 2015 . The specific objective was to establish the relationship between public sector expenditure and Gross Domestic Product (GDP), therefore data were collected on them. The celebrated contrary view of the Keynesian philosophy as against Wagner's Law on the relationship between public sector spending and economic growth became the bone of contention in this study. Notwithstanding the divergent empirical results on the subject matter, the empirical findings from this study established the existence of a positive and significant relationship between public sector expenditure and economic growth in Nigeria. The study therefore suggested a comprehensive and extensive macroeconomic transformation in the Nigerian public finance which must include clearness and operational application of budgetary process.

Oziengbe (2013), studied the relative impacts of federal capital and recurrent expenditures on Nigeria's economy using time series data covering a period from 1980 to 2011. Recurrent and capital expenditures were the explanatory variables while the GDP was the response variable. The Error Correction Model result revealed that each of the independent variables exerted insignificant positive impact on GDP in the short run, but later became statistically significant with a lag. Though the recurrent expenditure had a stronger impact than the capital expenditure. The paper suggested that government expenditure should be used to provide more infrastructures and public services. Aigheyisi (2013) examined the impacts of federal capital and recurrent expenditures on Nigeria's economy using time series data that covered the period from 1980 to 2011 . The data were collected on Gross Domestic Product (GDP as the dependent variable), total expenditure, foreign direct investment, remittances and foreign aids. The co-integration test result indicated the existence of a long-run relationship between GDP and the independent variables. The paper recommended adequate provision of infrastructures and more capital investment to boost economic growth in the country.

Ogundipe and Oluwatobi (2011) examined the effect of government spending on economic growth in Nigeria using Johansen technique for the period covering 1970 to 2009. The study was concerned about the deteriorating state of social and human capital in the economy despite the huge foreign earnings. The data employed for the study were collected from CBN, Statistical Bulletin and were collected on RGDP (dependent variable), government spending on administration, economic services, social and community services, and transfers (Independent variables. The result showed that total expenditure (except education and health) had insignificant negative influence on growth, but that in the long run, capital expenditure might exert a significant positive impact on growth rate. The study suggested an adequate handling of recurrent and capital expenditure for a better economic sustainability.

\subsection{Gap in literature}

Most studies revised above focused on the effect of government capital expenditure on economic growth and development. Kalemi and Prodani (2015) considered the influence of macroeconomic factors on public capital outlays in Albania using Wagner Model and time series data spanning from 1996 to 2013. This present study is dedicated to determining the effect of some factors on public capital investments in Nigeria in the millennium period. This period in the country's political scene, is also the democracy era.

\section{Methodology}

The study employed ex post facto research design which involves the use of existing data that are not under the control of the researcher. In other words, the researcher does not need to perform any form of experiment to derive the data. The data span from 2000 to 2017 and have been obtained from 
the Central Bank of Nigeria, Statistical Bulletin 2017 edition and World Bank. The secondary data were collected on government capital expenditures (CEXD), total government expenditure (TEXD), real GDP (RGDP), debt servicing (DSVG), inflation rate (INFL), exchange rate (EXGR), population (PPLN).

In line with the literature, both dependent and independent variables have been recognized, the data on CEXD, TEXD, RGDP, DSVG are in billions of Naira (local currency), while others are in other values. So, logarithm was applied to harmonize the values.

The model used for the study was adopted from Kalemi and Prodani (2015) but with modifications suitable for this current study.

The functional form of this model is shown below:

CEXP $=$ F $($ TEXP, RGDP, DSVG, INFL, EXGR, PPLN)

Where:

$\begin{array}{lll}\text { CEXD } & = & \text { capital expenditures (Dependent variable) } \\ \text { TEXD } & = & \text { total government expenditures (Independent variable) } \\ \text { RGDP } & = & \text { real GDP (Independent variable) } \\ \text { DSVG } & = & \text { debt servicing (Independent variable) } \\ \text { INFL } & = & \text { inflation rate (Independent variable) } \\ \text { EXGR } & = & \text { exchange rate (Independent variable) } \\ \text { PPLN } & = & \text { the population (Independent variable) }\end{array}$

\section{Data Analysis and Interpretations}

Table 1: Model Summary of results

\begin{tabular}{|c|c|c|c|c|c|}
\hline Model & $\mathrm{R}$ & R Square & Adjusted R Square & Std. Error of the Estimate & Durbin-Watson \\
\hline $\mathbf{1}$ & .982 & .965 & .946 & .05127009 & $\mathbf{2 . 1 7 4}$ \\
\hline
\end{tabular}

a. Predictors: (Constant), DSVG, INFL, EXGR, TEXD, RGDP, PPLN

b. Dependent Variable: CEXD

Source: Author's computation, 2019

From table 1 above, the $\mathrm{R}$ value is $98.2 \%$ implying that the correlation between Government capital investment (CEXD) and the selected macroeconomic factors (DSVG, INFL, TEXD, EXGR, PPLN \& RGDP) is very strong. In the same manner, the R Square of $96.5 \%$ indicates the extent to which the explanatory variables are able to explain the variation in the CEXD. Therefore, it is obvious that only $3.5 \%$ of the changes could be attributed to other factors that are not included in the model. The Durbin-Watson of 2.17 shows the absence of a serial correlation.

Table 2: ANOVA

\begin{tabular}{|l|c|c|c|c|c|}
\hline Model & Sum of Squares & Df & Mean Square & F & Sig. \\
\hline Regression & .802 & 6 & .134 & 50.847 & .000 \\
Residual & .029 & 11 & .003 & & \\
Total & .831 & 17 & & & \\
\hline
\end{tabular}

a. Dependent Variable: CEXD

b. Predictors: (Constant), DSVG, INFL, EXGR, TEXD, RGDP, PPLN

*** $=$ Significant at $1 \%$

Source: Author's computation, 2019. 
Table 2 above shows that F-statistic is 50.847 with the p-value of $0.000<0.05$ level of significance. The result discloses that the model is statistically significant and suitable for the study. The result also suggests that all the explanatory variables influence federal government capital expenditure collectively and significantly.

Table 3: Regression Coefficients

\begin{tabular}{|l|c|c|c|c|c|}
\hline \multirow{2}{*}{ Model } & \multicolumn{2}{|c|}{ Unstandardized Coefficients } & Standardized Coefficients & \multirow{2}{*}{$\mathrm{t}$} & \multirow{2}{*}{ Sig. } \\
\cline { 2 - 5 } & $\mathrm{B}$ & Std. Error & Beta & & 1.369 \\
(Constant) & 16.633 & 12.151 & & .198 \\
TEXD & 1.420 & .271 & 1.924 & 5.234 & $.000^{* * *}$ \\
RGDP & -.555 & .606 & -.389 & -.916 & .380 \\
PPLN & -2.166 & 1.633 & -.603 & -1.326 & .212 \\
INFL & .052 & .117 & .035 & .441 & .668 \\
EXGR & 1.334 & .505 & .504 & 2.643 & $.023^{* *}$ \\
DSVG & -.402 & .138 & -.625 & -2.908 & $.014^{* * *}$ \\
\hline
\end{tabular}

a. Dependent Variable: CEXD

b. Predictors: (Constant), DSVG, INFL, TEXD, EXGR, PPLN, RGDP

$* * *=$ Significant at $1 \% ;{ }^{* *}=$ Significant at $2 \%$

Source: Author's computation, 2019

The result on table 3 establishes that the relationship between public capital investment and the explanatory variables can be expressed using the following regression model:

$\mathrm{Y}=16.633+1.420 \mathrm{TEXD}-0.555 \mathrm{RGDP}-2.166 \mathrm{PPLN}+0.052 \mathrm{INFL}+1.334 \mathrm{EXGR}-0.402 \mathrm{DSVG}$

\subsection{Test of hypothesis}

Ho1: Total expenditure does not have significant impact on the public capital investment

The study has earlier stated that total expenditure does not have significant influence on public capital investment in Nigeria. From table 3 above, the regression result indicates that TEXD t-statistic is 5.234 with the p-value of $0.000<0.05$ significance level. This result implies that TEXD has a robust positive and significant impact on public capital investment in Nigeria. So, Hor is rejected and the alternative which states otherwise accepted.

Ho2: Real GDP does not significantly affect the public capital investment

The study initially postulated that RGDP does not significantly influence public capital investment. From table 3 above, RGDP t-statistic is -0.916 and has a p-value of $0.380>0.05$ significance level. This result implies that RGDP has insignificant negative impact on government capital investment. So, the $\mathrm{Hoz}$ is established and the alternative assumption is hereby decline. Thus changes in the RGDP whether negative or positive portrays the level of income flow which determines the degree of capital expenditure the government will be willing to undertake in order to reduce the level of abandoned projects in the country.

Ho3: Population does not have significant influence on public capital investment

The study has suggested earlier that the number of people in Nigeria does not have significant impact on government capital investment. In other words, the issue of increasing Nigeria's population might not be one of the challenges affecting capital projects' execution and completion in the country. From table 3 above, PPLN t-statistics is 
-1.326 and the p-value is $0.212>0.05$ level of significance. This result reveals that Nigeria's population exerts an insignificant negative influence on government capital investments, therefore, Hoz is accepted and the alternative hypothesis rejected. The point to note here is that, the increase in Nigeria's population is becoming an issue of concern, though not significant but it is negatively affecting the amount of capital investment the government can afford. This implication is that the increasing number of people in the country outweighs the budget for infrastructures and that the existing ones are inadequate to match with the population.

Ho4: Inflation does not have significantly effect on public capital investments

The earlier postulation of the study is that inflation does not have significant effect on public capital investments. From table 3 above, INFL t-statistic is 0.441 while the p-value is $0.668>0.05$. The result suggests that inflation does not have any impact on public capital investment, thus, $\mathrm{Ho}_{4}$ is hereby accepted and the alternation supposition rejected. This is an indication that inflation rate is not strong enough as to hinder execution of capital projects in the country.

Ho5: Exchange rate does not have significant influence on public capital investment

The study posited earlier that exchange rate does not have significant impact on public capital investments. The result on table 3 above shows that EXGR t-statistic is 2.643 and the $\mathrm{p}$-value is $0.023<0.05$. This result implies that exchange rate has a significant positive impact on capital expenditure and so $\mathrm{Ho}_{5}$ is rejected and the alternative assumption is accepted. The implication is that exchange rate is not harsh to government capital spending and cannot influence it negatively.

Ho6: Debt servicing does not have significant effect on public capital expenditure in Nigeria

The earlier assumption is that debt servicing in Nigeria does not affect capital expenditure. The result on table 3 above depicts that DSVG t-statistics is -2.908 and the p-value is 0.014 $<$ 0.05. This result shows that DSVG has a significant negative influence on capital investment and so Ho6 is hereby rejected and the alternative is accepted. In other words, the government spends more on servicing debt and cannot adequately perform the responsibility of meeting the needs of the citizens.

\section{Conclusion and Recommendations}

\subsection{Conclusion}

The findings of this study have a lot of policy implications. Firstly, it is imperative to note that the country has not produced sufficient domestic goods and services to increase the RGDP, hence it's adverse effect on CEXD. Secondly the population of the country is increasingly alarming, such that government expenditure on capital projects does not seem to meet the demands due to large population. Thirdly, the amount of revenue that goes into debt servicing from the government treasury affects capital investment adversely. The Nigeria Extraction Industries Transparency Initiative (NEITI) expressed concern over the high level of Nigeria indebtedness when compared with the revenue (Eboh, 2017). The amount of resources that go into debt servicing do not give room for quality investment on capital projects and infrastructures that could improve the living standard of people in the country. Macroeconomic variables like inflation and exchange rates do not affect capital expenditure or investment so much. As a matter of fact exchange rate has a significant positive impact as well as the total expenditure.

\subsection{Recommendations}

Following the outcome of this study, the following recommendations have been made: 
- The study suggests that the policy makers should focus more on how to boost the RGDP, curtail the government borrowing habit and enact laws that could checkmate the population growth in the country.

- The government should create an enabling environment for businesses to thrive. This includes encouraging domestic industries to grow and making room for foreign direct investments (FDI). If the business environment is favorable and conducive, FDI inflows will be attracted and local industries will also thrive. Therefore, a stable political and socioeconomic environment will help to improve businesses which in turn will boost the RGDP. These measures could help to cope with the increasing government spending on infrastructures and capital projects.

- The Central Bank of Nigeria $(\mathrm{CBN})$ should employ its monetary tools to manage inflation in the economy. Every aspect of the economy that will cause inflation should be put under strict control. Inflation is usually caused by excess money in circulation, with this in mind, the CBN must ensure that money supply does not exceed the level of economic activities in the country.

- The government should encourage every economic move to boost the value of the local currency (Naira) and stabilize exchange rate. This may involve encouraging more exports and reducing the level of imports. Exchange rate volatility does not enhance budget implementation as a result if execution of public capital projects is confronted with currency fluctuation, such projects may suffer financial drawbacks where the budget falls below the prevailing prices of materials.

- It is usually beneficial to maintain a higher capital expenditure than recurrent expenditure. Thus, the government may consider adjusting the total expenditure in favour of the capital expenditure by reducing the recurrent expenditure.

\section{Acknowledgement}

The Author thanks the editors and anonymous reviewers of the Journal of Educational and Social Research for their valuable contributions that enriched the quality of this paper.

\section{References}

Accounting Tools (2017). Examples of capital expenditures. Retrieved on May 28, 2018 from: https://www.accountingtools.com.

Aigheyisi, O. S. (2013). The relative impacts of Federal capital and recurrent expenditures on Nigeria's economy (1980-2011). American Journal of Economics, 3(5), 210-221.

Controller of Budget (2015). What is recurrent expenditure? Office of the controller of budget, Republic of Kenya. Retrieved from: cob.go.ke/ufaqs on May 28, 2018.

Eboh, M. (2017). Nigeria's debt reaching critical levels - NEITI. Retrieved on May 20, 2018 from: https://www.vanguardngr.com.

Focus Economics (2018). Inflation rate (CPI, annual variation in \%). Retrieved on May 28, from: https://www.focus-economics.com.

Idris, M., \& Baker, R. (2017). Public sector spending and economic growth in Nigeria: in search of a stable relationship. Asian Research Journal of Arts and Social Sciences, 3(2), 1-19.

Kalemi (Jakupi), V., \& Prodani, G. (2015). The impact of macroeconomic factors in public capital expenditures in Albania. European Journal of Sustainable Development, 4(1), 51-62.

Kapunda, S. S., \& Topera, J. S. (2013). Public expenditure composition and economic growth in Tanzania: socioeconomic policy implications. Asian African Journal of Economics and econometrics, 3(1), 61-70.

Kimaro, E. L., Keong, C. C., \& Sea, L. L. (2017). Government expenditure, efficiency and economic growth: a panel analysis of Sub Saharan African low income countries. African Journal of Economic review, 5(2), 34-54.

Maingi, J. N. (2017). The impact of government expenditure on economic growth in Kenya: 1963-2008. Advances in Economics and Business, 5(12), 635-662. 
My Accounting Course (2018). What is Real GDP? Retrieved on May 20, from: https://www.myaccountingcourse.com.

My Accounting Course (2018). What is Debt Service? Retrieved on May 28, from: https://www.myaccountingcourse.com.

Nguyen, H. Q. (2017). The role of public expenditures in economic growth at provincial level: Empirical study in Vietnam. Journal of Politics and Law, 10(2), 88-96.

OECD (2018). Population (indicator). Organization for Economic Co-operation and Development. Doi: https://data.oecd.org/pop/population.htm.

Ogundipe, A. A., \& Oluwatobi, S. (2011). Government spending and economic growth in Nigeria: Evidence from disaggregated analysis. Department of Economics, Covenant University Ota.

Omodero, C.O. (2019). Government general spending and human development: A case study of Nigeria. Academic Journal of Interdisciplinary Studies, 8(1), 51-59. DOI: 10.2478/ajis-2019-0005.

Oziengbe, S. A. (2013). The relative impacts of Federal capital and recurrent expenditures on Nigeria's economy (1980-2011). American Journal of Economics, 3(5), 210-221.

Peacock, A. T., \& Wiseman, J. (1961). The growth of public expenditure in the United Kingdom. London: Oxford University Press.

Peacock, A. T., \& Wiseman, J. (1979). Approaches to the analysis of government expenditure growth. Public Finance Quarterly, 7, 3-23.

The City of Portland Oregon (2018). Definition - what is a capital project? City Budget Office. Retrieved on May 20, from: https://www.portlandoregon.gov/cbo/article/50495.

The Economic Times (2018). Definition of exchange rate. Retrieved on May 28, from: https://economictimes.indiatimes.com.

Wagner, A. H. (1883). Finanzwissenschaft. Leipzig: C.F. Winter. 